$\xi=-1$

\title{
A Legal and Organizational Prospects for Improvement the Placement Process of the State Order for Specialists Training
}

\author{
Yuriy Pyvovar $^{1 *}$ Iryna Pyvovar $^{2}$, Julia Iurynets $^{1}$ \\ ${ }^{1}$ Professor, Department of Constitutional and Administrative Law, National Aviation University, Kyiv, Ukraine \\ ${ }^{2}$ Associate Professor, Department of General Legal Disciplines, Institute of Criminal-Executive Service, Kyiv, Ukraine \\ *Corresponding author E-mail: PyvovarYI@nau.edu.ua
}

\begin{abstract}
Since 2013 with the gradual integration of Ukraine into the European and Global education space, there is a need to reduce the state's financial expenses on specialists training and to change the principles of the formation, placement and performance (this triad represents the consecutive stages) of the mechanism of the governmental order in the field of education. Thereof it is suggested to determine the main objective, namely, prospects for improvement the mechanism of organization and legal groundwork for effectuation of placement of the governmental order for the specialists training for the state needs. The main results of the work became: firstly, the systematization of subjects involved in the process of placing the governmental order for specialists training. It was established that the main organizational guarantor in this process is the Cabinet of Ministers of Ukraine; the main coordinator is the Ministry of Economy and Development of Ukraine; the main performers of the order placement are governmental customers; placement targets are government performers. Secondly, two forms of administrative procedures for the performance of the governmental order placing are distinguished: 1) the public procedure of the competition for performers of the governmental order; 2) simplified (non-competitive) procedure for the appointment of performers of the governmental order. Within these procedures, organizational (institutional) and legal guarantees of their performance are described. The new achievements of the study became suggestions: firstly, introduction of a competitive procedure in the placement process of the governmental order for specialists training for the law enforcement agencies, as well as the implementation of a contractual procedure of signing state contracts for the performance of the governmental order between law enforcement agencies (governmental customers) and performers of the governmental order; secondly, to legalize in the law the procedure of conducting a competition among educational institutions of different departments with the purpose of choosing suitable ones for the governmental order performance; thirdly, to empower the Ministry of Economy and Development of Ukraine to agree the provisions of all governmental customers, the work of the Competition Committee on the selection of performers of the governmental order, as well as on the development of a typical procedure for the work of such Committees.
\end{abstract}

Keywords: State Order, Specialists Training, Governmental Customers, Performers of the Governmental Order, Administrative Procedures, Selection of Performers

\section{Introduction}

Over a period of five years, Ukrainian society has been actively implementing a variety of political and economic experiments in the educational sector in search of an optimal model for meeting the needs of society in educational services, while balancing the interests of the state and the population. Under the conditions of Euro-Atlantic integration of Ukraine, such search is accompanied by a dynamic development of domestic legislation; changing the format of state institutions, principles and order of interaction between state bodies of executive power and local selfgovernment bodies; gradual reduction of the number of state higher education institutions; change of priorities of state needs in the field of education, etc. Under such conditions, the mechanism of the governmental order for training of specialists, scientific, teaching and worker staff, advanced training and retraining (hereinafter - educational governmental order) as the main means of state regulation of educational services at public expense requires timely and appropriate adaptation, organizational and legal security guarantees.
Considering the mechanism of educational governmental order in terms of procedural viewpoint, it is necessary to distinguish three main stages: 1) the stage of formation of the governmental order (the main task of which is determination of quantitative and qualitative indicators, which characterize educational needs of the state and society, the needs of the labor market in professional staff, the satisfaction of which is planned to be carried out at the expense of the state budget);2) the stage of placement of the governmental order (the main purpose of which is to determine the performers of the governmental order and delegate to them the educational function of the state for providing educational services to the population by governmental customers); 3) the stage of the governmental order performance (the most time-consuming, capacious by the participants number and the most expensive stage by the amount of expenses and resources, which consists in the ultimate goal of the governmental order achieving - the obtainment of educational products). Undoubtedly, each of these stages is an important, complex and at the same time vulnerable to the influence of external (objective) and internal (subjective) factors. In particular, guarantees of organizational and legal nature are intended to resist or adapt from the negative impact. 
Therefore, the work focuses on the research of the second stage of the educational governmental order, in order to determine the prospects for improvement the mechanism of organization and legal ensuring (i.e. organizational and legal guarantees) of efficient and rational placement of the governmental order for specialists training for the state needs. In addition, the public nature of the governmental order institution narrows the subject of our research to the studying of administrative and legal guarantees.

\section{Results and Discussion}

\subsection{Administrative Guarantees of the Educational Gov- ernmental Order}

Based on the most representative administrative and legal concept of organizational and legal guarantees system understanding, we distinguish two main groups of administrative guarantees of the educational governmental order, that are basic for studying: 1) organizational are institutions determined by the legislation, vested with the necessary functions, powers for organization and implementation of administrative and legal ensuring of implementation and protection of the interests of participants in the governmental order in the field of education; 2) legal are administrative procedures established by regulatory and legal acts (for example, rule-making, registry, licensing, accreditation, competitive, control, appeal, settlement of disputes, etc.).

In terms of these groups of guarantees we define the institutional (organizational) guarantees as well as administrative procedures, in which the interests that arise at the stage of placement of the educational governmental order of the participants of relations are ensured.

\subsection{Administrative Procedures as a Form of Legal Guarantees for the Placement of an Educational Gov- ernmental Order}

In the theory of Ukrainian administrative law, Doctor N. L. Huberska interprets the administrative procedure as an established normative procedure of the consistent implementation of the actions of public administration bodies aimed at the adoption of powerful managerial decisions and implementation of powers not related to adjudgements or enforcement measures [1]. This approach really deserves attention, but we prefer the concept of a broad ("managerial") understanding of the concept of an administrative procedure. Firstly, we believe that administrative procedures can be carried out not only by public administration bodies but also by other authorized subjects on the basis of powers delegated to them by the public administration or by the law (for example, state and municipal educational institutions). Secondly, we defend the scientific position according to which administrative procedures are used both in non-jurisdictional and jurisdictional proceedings (for example, during administrative adjudgements in extrajudicial procedure; bringing law breakers to disciplinary and administrative liability).

The mentioned position and the results of the analysis of the current legislation give grounds to distinguish two main forms of implementation of the placement of governmental orders, which serve as a kind of administrative procedures. These procedures, on the one hand, take into account the needs of governmental customers, on the other hand, take into account the capabilities and suitability of potential performers of governmental orders, are carried out on the basis of the law, and therefore absolutely justifiably can serve as legal guarantees for governmental orders placement.

Such administrative procedures are:

firstly, the procedure for the competitive selection of governmental order performers, the general requirements for which are set forth in the Law of Ukraine № 5499-VI (part 1, Art. 3) (Law,
2012) [2] and the Resolution of the Cabinet of Ministers of Ukraine (hereinafter - the CMU) of May 20, 2013 № 363 [3], and is based on the principles of fair competition, openness and transparency, objective and unbiased evaluation of the proposals of the participants of the competition. The detailed procedure for conducting such competitions is regulated by the administrative normative act of governmental customers (for example, the Orders of the Ministry of Culture of Ukraine "On Approval of the Regulation on the Work of the Competition Committee of the Ministry of Culture of Ukraine on Selection of Performers of Governmental Order for Training of Specialists, Teaching and Scientific Staff and Advanced Training” of July 03, 2014 № 521 [4]; the Order of the Ministry of Education and Science of Ukraine "On Approval of the Regulation on the Competition Committee of the Ministry of Culture of Ukraine on Selection of Performers of Governmental Order for Training of Specialists, Scientific, Teaching and Worker Staff, Advanced Training and Retraining" of May 30, 2013 № 646 [5].

Secondly, a simplified (non-competitive) procedure for appointment of performers of the governmental order, whose legal grounds are laid down in the Law № 5499-VI (part 2, Art. 3) [2]. This procedure is provided in the following cases:

1) for the defence of Ukraine;

2) for ensuring state security and protection of the state border;

3) for providing the Armed Forces of Ukraine;

4) for providing the Security Service of Ukraine;

5) for providing other military formations and law-enforcement bodies, civil defense services, the organization and procedure of which are determined by law;

6) ensuring of training of specialists in the correspondence with specialty by one educational institution according to the given license;

7) existence of a specific agreement on the providing of educational services between the educational institution and the customer of personnel [2].

Obviously, the simplicity of this procedure in these cases does not deprive it of normative regulation, therefore, administrative acts, that define the regulation of placement of a governmental order are orders of the central executive authorities, which acts as the governmental customers of training (retraining, advanced training) of the corresponding personnel. For example, such acts are the Order of the Administration of the State Service for Special Communications and Information Protection of Ukraine "On Approval of the Regulation on the Procedure and Terms of Continuing Professional Training and Retraining of Personnel in the State Service for Special Communications and Information Protection of Ukraine" dated 16/09/2014 № 461, in which by a separate section are regulated "VI. Peculiarities of financing, formation and placement of a governmental order for advanced training and retraining of the State Social Communication Service" [6]; the Order of the Ministry of Interior of Ukraine "On Approval of the Order on Training Seeking Students Seeking the Degree of Doctor of Philosophy and Doctor of Sciences in Research Institutions that are under the Ministry of Interior of Ukraine Management Sphere and Higher Educational Institutions with Specific Studying Conditions that Train Staff for the Ministry of Interior of Ukraine and the National Police of Ukraine" 28.11.2017 № 963, which states that "the division of the governmental order for Training of Scientific and Teaching Staff for the needs of the Ministry of Interior of Ukraine and the National Police of Ukraine is carried out by the Department of Personnel, Organizations of Educational and Scientific Activities of the Ministry of Interior of Ukraine" [7].

The legal analysis of these and many other similar regulations indicates, on the one hand, the fully substantiated independence of predominantly law enforcement and other paramilitary forces as governmental customers in choosing the procedures and making decisions on placing a governmental order for staff training in its jurisdictional educational institutions. On the other hand, in the cases, when there are two or more educational institutions in the field of management of such governmental customers, we consid- 
er it necessary to organize the Competition on the Selection of Performers of Governmental Order.

\subsection{Public Institutions as Forms of Organizational Guarantees for the Placement of Educational Govern- mental Orders}

In general terms, public institutions in the field of educational governmental order are legal entities under public law, authorized to perform functions aimed at the formation and implementation of state policy in the field of governmental order for training, retraining and advanced training of the staff for state needs.

The leading organizational role in ensuring the guarantee of effective and proper implementation of the placement of the educational governmental order is played by the CM of Ukraine, the Ministry of Economic Development and Trade of Ukraine, and governmental customers.

Thus, the importance of the CM of Ukraine as a participant in this stage is to establish a general mechanism of placement of the educational governmental order, which is accomplished by governmental customers on a competitive basis, including establishing the main criterion and procedure of selecting governmental order performers.

As to the role of the Ministry of Economic Development and Trade of Ukraine in the process of placing the educational governmental order, it should be noted that its authority at this stage is insufficiently certain. On the one hand, paragraph 2, part 1, Art. 2 of the Law of Ukraine № 5499-VI, this authority is defined as the main coordinator of the activities of governmental customers concerning the placement and performance of the governmental order [2]. The same regulation is duplicated in sub-paragraph 18, paragraph 4 of the Regulation on the Ministry of Economic Development and Trade of Ukraine, and it is stated that the Ministry of Economic Development and Trade of Ukraine, in accordance with its tasks, coordinates the work of governmental customers on its placement [8]. On the other hand, in the special Resolution of the Cabinet of Ministers of Ukraine of May 20, 2013 № 363, powers of the Ministry of Economic Development and Trade of Ukraine are not determined, we consider it to be inadmissible. One of the functions, that, in our opinion, should be reflected in the specified legislative act and duplicated in the Resolution № 363 of May 20, 2013 [3], is the procedure of approval of the regulations on the work of the Competition Committee of governmental customers for selection of performers of the governmental order for training of specialists, scientific, teaching staff and advanced training by the Ministry of Economic Development and Trade of Ukraine.

The next institutional component of organizational and legal guarantees for the placement of the educational governmental order form governmental customers.

Before turning to the analysis of the powers of governmental customers at the stage of placing the governmental order, we draw attention to such a group of subjects as Council of Ministers of the Autonomous Republic of Crimea, regional state administrations, Kyiv and Sevastopol state administrations. (all of them are local bodies of the state executive authority).

On the one hand, according to the Law of Ukraine №5499-VI [2], the mentioned authorities are referred to governmental customers, obviously provide for them prospects to acquire a full range of powers typical for governmental customers (having in mind participation in the full cycle of this mechanism - from the creation of an order for meeting state needs on corresponding regional level to obtaining trained specialists with the fulfillment of their respective functions of the state). On the other hand, practically, the division of the governmental order (including the governmental order, which was formed according to the indicators, the needs of the mentioned regional state authorities) takes place between the governmental customers, passing by the Council of Ministers of the Autonomous Republic of Crimea, regional state administrations, Kyiv and Sevastopol state administrations. An example of this are the resolutions of the Cabinet of Ministers of Ukraine of July 1, 2015, № 462, of July 6, 2016, № 408 etc., in which all amounts of the governmental order for worker staff training for the regions were provided to the Ministry of Education and Science of Ukraine.

In such a situation, we consider it expedient to exclude local bodies of the state executive authority from Art. 1 of the Law № 5499-VI [2] as the governmental customers and leave them only a function concerning making of a medium-term forecast of the needs of the state in specialists and worker staff on the labor market and presenting these forecasts to the Ministry of Economic Development and Trade of Ukraine for generalization into the united national forecast. The logic of this proposal is also proved by the legal status of these state authorities in the budget process as the main administrators of local budgets (obviously for providing local needs in educational services), rather than the State Budget, which is subject to the financing of educational governmental order.

Within the framework of the above-mentioned administrative procedures of governmental order placement, we propose to classify the governmental customers into two groups: 1) governmental customers, who carry out the placement of the governmental order on a competitive basis; 2) government customers, who carry out the placement of the governmental order under a simplified (outof-competition) procedure. Obviously, according to the current legislation, the subjects of these groups differ in their powers.

Thus, the main types of regulatory activities of governmental customers of the first group while placing the governmental order are: 1) the development and approval of the regulation on the work of the Competition Committee (as a rule, the appropriate administrative act, which is made and approved by the governmental customer once, is a long-term one and can be changed every year. For example, the Regulations on the Competition Committee of the Ministry of Culture of Ukraine on Selection of Performers of Governmental Order for Training of Specialists, Scientific, Teaching and Worker Staff, Advanced Training and Retraining: the Order of the Ministry of Education and Science of Ukraine of May 30, 2013 № 646 [9]. The analysis of this and some other regulations developed by various governmental customers gives grounds to call them one-type (they contain the same structure and have mainly reiterative content). In view of the foregoing and in order to unify such regulations (it will reduce the risks of abuse by governmental customers during setting the rules of work of the Competition Committee), we consider it is rational to authorize the Ministry of Economic Development and Trade of Ukraine to develop a standard regulation on the work of the Competition Committee, which would serve as a model for all governmental customers. We propose to implement this idea in the resolution of the Cabinet of Ministers of Ukraine "On Approval of the Order on Placing Governmental Orders for Training of Specialists, Scientific, Teaching and Worker Staff, Advanced Training and Retraining: Resolution of the Cabinet of Ministers of Ukraine № 363 of May 20, 2013 [3].

2) formation and approval of the Competition Committee Members. In accordance with the requirements of the Resolution of the CMU № 363 of May 20, 2013, such Competition Committee should include representatives of: a) the governmental customer; b) the Ministry of Education and Science of Ukraine; c) the Ministry of Economic Development and Trade of Ukraine; d) expert councils attached to the Accreditation Council; e) the joint representative body of employers on the national level; f) the joint representative body of national trade unions and trade union associations; g) student self-government bodies. At the same time, the legal restriction in this process is the prohibition to involve the representatives of participant of the competition (the competitor) to the Competition Committee Members. Approval of he Competition Committee Members is carried out in the form of an administrative regulation - an order of the governmental customer (for example, the order of the Ministry of Education and Science of Ukraine of June 13, 2017, № 843 "On Approval of the Competi- 
tion Committee Members on Selection of Performers of Governmental Order for Training of Degree-Seeking Students and Work Staff, Advanced Training and Retraining in the year 2017" [10];

3 ) development and approval of the competition procedure;

4) the development and approval of the criterion for competitive selection, the list and samples of competition documentation, the requirements for the competitive proposals, the form of the governmental contract, which is concluded between the governmental customer and the performer of the governmental order, which belongs to the sphere of its management, as well as the procedure for amending the governmental contract (para. 4). The relevant criterion are developed by each governmental customer, taking into account the specifics of the governmental order under each category of educational services: for the training of masters, bachelors, doctors of philosophy, retraining and advanced training (for example, the order of the Ministry of Education and Science of Ukraine of June 14, 2017, № 858 "On Approval of the Regulation on the Criteria of Placing Governmental Order for Training of Masters for Higher Educational Institutions that are under the Ministry of Education and Science of Ukraine Management Sphere" [11] the order of the National Agency of Ukraine on Civil Service of August 12, 2016, № 163 "On Approval of Standard Governmental Contracts on Providing Services in Training of Masters in the Specialty "Public Management and Administration", Advanced Training of Civil Servants and Local Government Officials, Standard Additional Agreements to Governmental Contracts, Standard Acts on Providing Services" [12].

5) announcement of the competition. Administrative procedure of its implementation is legal guarantees for carrying out this type of regulatory activity of governmental customers, which provides: firstly, its implementation within five days after approval of the governmental order for training specialists for the relevant year as required by the law (para. 5); secondly, it is carried out by publishing the announcement and information on conducting the competition in the official printed publication, and placing it on its own official website of the Ministry of Education and Science of Ukraine (para. 6); thirdly, by detailed filling of such announcement, which involves publication of information about the location of a governmental customer; the amounts of governmental order for training of specialists, scientific, teaching and worker staff, advanced training and retraining in the current year; the procedure for providing explanations on the issues of conducting the competition; the address at which the documentation on competition can be obtained; requirements for competition proposals competitive admissions criteria; the term of submission of competition proposals; date and time of consideration of the proposals; surname, name and patronymic name, position and contact numbers of one or several authorized persons of the governmental customer (para.7). The announcement of the Ministry of Culture of Ukraine for the selection of governmental order performers for training of specialists, teaching, scientific staff and advanced training in the year 2017 among higher educational institutions that are under the Ministry of Culture management sphere [13], which was carried out within the timeframes stipulated by the above requirements can be an example of this procedure;

6) returning competition proposals without consideration in cases, if they came after the specified term of their acceptance, or those which do not meet the established requirements (para. 10);

7) drawing up the minutes of the competition proposals (para. 11); 8) giving a copy of the competition proposal minutes to the participants upon their request within three working days from the date of receipt of the corresponding request (para. 11);

9) informing each participant about the results of the competition. The main requirement for such informing is the term - it should not exceed 10 working days from the date of consideration of the competition proposals, determination of potential performers of the governmental order (para. 13). We consider the publication of an administrative act by state enforcement officers in the form of an order on the results of the competitive selection with the distribution of amounts of the order between the performers of the gov- ernmental order as a positive practice (for example, the order of the National Agency of Ukraine on Civil Service dated July 29, 2016, № 148 "On approval of the amounts of governmental order for the preparation of masters in the specialty "Public Management and Administration" of the field of knowledge "Management and Administration" and advanced training of civil servants and local government officials in the year 2016", in which the governmental customer has clearly allocated the amounts of the governmental orders for the training of masters in the speciality "Public Management and Administration" of the field of knowledge "Management and Administration", and for advanced training of civil servants and local government officials on anti-corruption issues in the year 2016) [15];

10) concluding a governmental contract with the performer of the governmental order, which specifies the economic and legal obligations of the parties and regulates the relationship between the customer and the performer, as well as changes in a governmental contract in case of need (para. 14).

Within the second type of administrative procedures for the selection of the performers of the governmental order, namely noncompetitive appointment of the performers, the regulatory activities of the relevant governmental customers are characterized by a smaller amount of authority. At the same time, the regulation of such powers is provided mainly by departmental instructions, which are usually concluded on the basis and in the light of educational legislation and sectoral legislative acts that define the tasks, functions and other peculiarities of the activity of the relevant agency (military, law enforcement service, etc.).

A general overview of the main legislative acts regulating the activities of certain law enforcement and other paramilitary government bodies makes it possible to indicate the obligatory conclusion of contracts in the field of educational governmental orders. At the same time, it is indicated that according to the general rule, their conclusion is made at the next stage after the implementation of the governmental orders, namely, at the stage of performing. This is due to the tripartite nature of such contracts, one of the parties of which is a student. And the results of the placement (distribution) of the governmental order for specific performers of the governmental order are carried out by "simplified" governmental customers in the form of a regulatory administrative act an order. For example, the Regulation on the higher military educational institutions of the Ministry of Defence of Ukraine regulates that the governmental orders for the training of military specialists is distributed among higher military educational institutions each year by the Order of the Ministry of Defence of Ukraine on admission to higher military educational institutions of auditors (students, military students) in various forms of education (para. 1.12) [16].

Based on the peculiarities of placing governmental orders under a simplified procedure, we consider that the norm of general action by the scope of persons (part 3, Art. 3 - should be applied to all governmental customers without any reservations) in the Law of Ukraine № 499-VI, which states that "A governmental customer concludes a governmental contract with the performer of the governmental order, which defines the economic and legal obligations of the parties and regulates the relationship between the customer and the performer", requires substantial refinement with the specification of its implementation.

The final group of institutional subjects of the mechanism of guaranteeing the implementation of educational governmental order at the stage of placement for consideration is: higher, vocational and technical educational institutions, institutions of postgraduate education, and scientific institutions of state and communal ownership (hereinafter - educational institutions). Based on the above division of procedures (competitive and non-competitive) for selecting performers of governmental order, we propose to divide these educational institutions into the following groups:

1) performers-contestants, which should contain educational institutions, participating in an open competition. But, obviously, not all of them acquire the status of the performer of the governmental 
order (in case of refusal to allocate places for them to train degreeseeking students for budget resources), respectively, they do not acquire new rights and responsibilities and do not continue their participation in the educational governmental order.

According to the current governmental procedure of placing governmental order on a competitive basis, the main competencies of the contestants are reduced only to the collection and submission of the necessary documents to the competition committee for the selection of performers of the order. And in cases of a positive decision of the committee on approval of the candidacy of the institution / establishment as a performer of the order, it has additional obligations to place the amounts of governmental order given to it in accordance with the concluded governmental contract in the Unified state electronic database for education issues, as well as powers coming out of the content of the governmental contract and other powers as a state-financed institution.

2) performers by appointment. Three sub-groups of educational institutions should be allocated within this group: a) the performers of educational governmental order for military formations and those equal to them (for providing the defence of Ukraine, state security and protection of the state border, the Armed Forces of Ukraine, the Security Service of Ukraine, other military formations and law enforcement agencies, civil protection service, the organization and operating procedures of which are determined by the law). Current state policy in the field of education provides that each military, law enforcement (defence and law enforcement) agency should contain a chain or at least one educational institution, retraining and advanced training center, which are created, reorganized or eliminated by the central authority under whose jurisdiction they are, or by their submission by the Cabinet of Ministers of Ukraine. For example, the main purposes of the activities of such institutions are: to provide the conditions necessary for a person to receive higher education, training specialists for agencies and subdivisions of the Ministry of Interior of Ukraine, other bodies of executive power, enterprises, institutions and organizations of Ukraine (para. 1.3) [17]; to carry out training, retraining, advanced training of military specialists at certain levels of higher education for further service in the positions of the officer (noncommissioned, precedence) or the senior officer personnel to meet the needs of the Armed Forces of Ukraine and other military formations formed in accordance with the laws of Ukraine (para.1.3) (Order, 2015). Control over compliance with the requirements of higher education standards, state inspection and educational and methodological guidance of the activities of such educational institutions are carried out by the Ministry of Education and Science of Ukraine and the Ministry of Interior of Ukraine (para. 1.12); b) monopoly performers, that is, educational institutions that provide speciality training in accordance with the granted license for monopoly status at the market of educational services (such specialties are usually new to the market and, therefore, for a certain period they may be provided by the most suitable educational institution at the market of educational services, and the number of such institutions is increasing, so the state of educational monopoly disappears); c) performers on a specific preliminary agreement on the provision of educational services between the educational institution and the customer of the staff. Obviously, the performers of all three groups may have different amount and type of authority, and moreover they may be different from the group of performers-contestants. However, at the stage of placing governmental orders formally, all these educational institutions are equal in the performance of such duty as the adding the amounts of governmental order given to these institutions into the Unified State electronic database on education issues.

\section{Conclusions}

Thus, the generalization of the results of this study gives grounds for concluding that the complex of organizational and legal guarantees for ensuring the placement of an educational governmental order is imperfect. We believe that all necessary organizational institutions have not been created in this process yet, and existing government actors are not able to properly ensure rational and efficient allocation of the amounts of educational governmental order. The Ministry of Economic Development and Trade of Ukraine is not fully involved in this process, so the expansion of its coordination and control powers is required. The administrative procedures for allocation of educational governmental order provided by the current legislation are mainly subjective, that is, they depend on the managerial will of the governmental customer. This creates potential threats to the conflict of interest (corruption) of governmental customers in relations with educational institutions, as well as conditions for improper implementation of the rights and interests of educational institutions regarding their participation in governmental programs for training specialists for the needs of the State for budget resources. The departmental noncompetitive system of appointment of governmental order performers is considered to be morally obsolete, imperfect, and unreasonably expensive for the State. Existing practice and legal basis for its regulation in the departmental law-enforcement (militarized) educational governmental order require in-depth research and reform.

\section{Authors' Contribution}

J.I. has generalized the legislation and defined the stages of the educational governmental order, outlined the direction of the study; Yu.P. has classified and described public institutions as a form of organizational guarantees for the placement of the educational governmental order; I.P. has identified and analyzed administrative procedures as a form of legal guarantees for the placement of the educational governmental order.

\section{Acknowledgments}

This work was supported in part by Department of Constitutional and Administrative Law research work is state budget theme «Public and legal mechanism of guaranteeing Ukraine's national interests» No. 55/13.01.02.

\section{References}

[1] Huberska, Natalia Leonidivna (2016), Administrative procedures in the field of higher education: abstract of doctoral dissertation in Law, Kharkiv: Yaroslav Mudryi National Law University. 2016. 37 p. Ukrainian.

[2] On Creating and Placing Governmental Orders for Training of Specialists, Scientific, Teaching and Worker Staff, Advanced Training and Retraining Verkhovna Rada of Ukraine, November 20, 2012. The Law of Ukraine No 5499-VI. Vidomosti Verkhovnoi Rady. 2014. 1; 6. Ukrainian.

[3] On Approval of the Order on Placing Governmental Orders for Training of Specialists, Scientific, Teaching and Worker Staff, Advanced Training and Retraining, May 20, 2013. Resolution of the Cabinet of Ministers of Ukraine No 363. Uriadovyi Kurier. 2013, May 28. 93. Ukrainian

[4] On Approval of the Regulation on the Work of the Competition Committee of the Ministry of Culture of Ukraine on Selection of Performers of Governmental Order for Training of Specialists, Teaching and Scientific Staff and Advanced Training, July 03 , 2014. Order of the Ministry of Culture of Ukraine No 521. Available from: http://zakon2.rada.gov.ua/laws/show/z0844-14/print. Ukrainian.

[5] On Approval of the Regulation on the Competition Committee of the Ministry of Culture of Ukraine on Selection of Performers of Governmental Order for Training of Specialists, Scientific, Teaching and Worker Staff, Advanced Training and Retraining, May 30 2013. Order of the Ministry of Education and Science of Ukraine No 646. Available http://zakon2.rada.gov.ua/laws/show/z0957-13. Ukrainian. 
[6] On Approval of the Regulation on the Order and Terms of Advanced Training and Retraining of Staff in State Service of Special Communications and Information Protection of Ukraine, September 16, 2014. Order of the Administration of State Service of Special Communications and Information Protection of Ukraine No 461 Ofitsiynyi Visnyk Ukrainy. 2014. 91; 548. Ukrainian.

[7] On Approval of the Order on Training Seeking Students Seeking the Degree of Doctor of Philosophy and Doctor of Sciences in Research Institutions that are under the Ministry of Interior of Ukraine Management Sphere and Higher Educational Institutions with Specific Studying Conditions that Train Staff for the Ministry of Interior of Ukraine and the National Police of Ukraine, November 28, 2017. Order of the Ministry of Interior of Ukraine No 963. Ofitsiynyi Visnyk Ukrainy. 2018. 4; 203. Ukrainian.

[8] The Ministry of Economic Development and trade of Ukraine Issues, August 20, 2014. Resolution of the Cabinet of Ministers of Ukraine No 459. Ofitsiynyi Visnyk Ukrainy. 2014. 77. Ukrainian.

[9] The Regulation on Competition Committee of the Ministry of Education and Science of Ukraine on Selection of Performers of Governmental Order for Training of Specialists, Scientific, Teaching and Worker Staff, Advanced Training and Retraining, May 30, 2013. Order of the Ministry of Education and Science of Ukraine No 646. Ofitsiynyi Visnyk Ukrainy. 2013. 48; 97. Ukrainian.

[10] On Approval of the Competition Committee Members on Selection of Performers of Governmental Order for Training of DegreeSeeking Students and Work Staff, Advanced Training and Retraining in the Year 2017, June 13, 2017. Order of the Ministry of Education and Science of Ukraine No 843. Available from: https://osvita.ua/legislation/Vishya_osvita/56239/. Ukrainian.

[11] On Approval of the Regulation on the Criteria of Placing Governmental Order for Training of Masters for Higher Educational Institutions that are under the Ministry of Education and Science of Ukraine Management Sphere, June 14, 2017. Order of the Ministry of Education and Science of Ukraine No 858. Available from: https://user.uteka.ua/uploads/599285d0f07ef.pdf. Ukrainian.

[12] On Approval of Standard Governmental Contracts on Providing Services in Training of Masters in the Speciality "Public Management and Administration", Advanced Training of Civil Servants and Local Government Officials, Standard Additional Agreements to Governmental Contracts, Standard Acts on Providing Services, August 12, 2016. Order of the National Agency of Ukraine on Civil Service No $163 . \quad$ Available from:http://nads.gov.ua/sites/default/files/imce/nakaz_nads_pro_dk _magistry_pk_2016.pdf. Ukrainian.

[13] The Announcement by the Ministry of Culture of Ukraine of the Competition on the Selection of Performers of Governmental Order for Training Specialists, Teaching and Worker Staff and Advanced Training in the Year 2017 among Higher Educational Institutions that are under the Ministry of Culture of Ukraine Management Sphere, July 12, 2017. Ministry of Culture of Ukraine. Available from:

http://mincult.kmu.gov.ua/control/uk/publish/article?art_id=245257 971\&cat_id=244931905. Ukrainian.

[14] On Governmental Order for Training of Specialists, Scientific Teaching and Worker Staff, Advanced Training and Retraining in the Year 2017, July 12, 2017. Resolution of the Cabinet of Ministers of Ukraine No 511. Uriadovyi Kurier. 2017, 134. Ukrainian.

[15] On Approval of the Amounts of Governmental Order for Training of Masters in the Speciality "Public Management and Administration" and Advanced Training of Civil Servants and Local Government Officials in the Year 2016, July 29, 2016. Order of the National Agency of Ukraine on Civil Service No 148. Available from: http://nads.gov.ua/sites/default/files/imce/nakaz_nads_pro_zatverdz hennya_obsyagiv_derzhavnogo_zamovlennya_0.pdf. Ukrainian.

[16] On Approval of the Regulation on Higher Military Educational Institutions, May 27, 2015. Order of the Ministry of Defence of Ukraine No 240. Ofitsiynyi Visnyk Ukrainy. 2015, 55: 858.Ukrainian.

[17] On Approval of the Regulation on Higher Educational Institutions of the Ministry of Interior of Ukraine, February 14, 2008. Order of the Ministry of Interior of Ukraine No 62. Ofitsiynyi Visnyk Ukrainy. 2008, 21: 112. Ukrainian. 